\title{
Impact of Employee Performance of IT Employees in Chennai During Covid - 19 Lockdowns
}

\author{
V. Sathyavathi" ${ }^{* 1}$, Dr. R. Angayarkanni ${ }^{2}$ \\ ${ }^{1}$ Department of Commerce, SRM IST, Kattankulathur, Tamilnadu, India. \\ ${ }^{2}$ Department of Commerce, Faculty of Science and Humanities, SRM IST, Kattankulathur, Tamilnadu, India. \\ *Corresponding author's E-mail: sathyavati2mraj@gmail.com
}

Received: 18-06-2020; Revised: 21-08-2020; Accepted: 28-09-2020; Published on: 20-10-2020.

\section{ABSTRACT}

The current COVID - 19 outbreak has had great economic consequences across the world. Millions of employees and workers have lost their jobs. Many organisations and companies are now facing issues on the operation of the company, employees are requested to work from home due to this COVID - 19 outbreaks. The office environment and home environment are totally different. To make home-office environment effective, it is necessary that employees and the management should take proper steps and measures. The study aims to bring out the impact of IT employee performance in Chennai during COVID - 19 Lockdowns. Both primary and secondary data used for the present study. The questionnaire has two sections, the first section consists of demographic information and the second section consists of five-point Likert scale questions on Work performance of employees during COVID - 19. Management should ensure that their teams have necessary tools to stay connected and work effectively.

Keywords: Corona virus, Employee performance, Work from home, IT employees.

QUICK RESPONSE CODE $\rightarrow$

DOI:

10.47583/ijpsrr.2020.v64i02.011

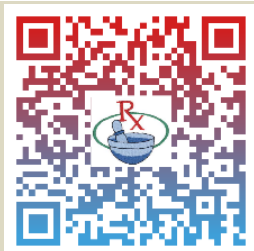

DOI link: $\underline{\text { http://dx.doi.org/10.47583/ijpsrr.2020.v64i02.011 }}$

\section{INTRODUCTION}

A

$\mathrm{n}$ organization to become successful it is necessary to have an effective life-force called human asset. People are the most important asset to the organization and it is accepted globally. The employees are the energy of the company that can increase the productivity, performance, profit and growth of the company. The development of the company is possible only when employees work hard to achieve the organization goals and they should compete with other competitors in the market. It is possible only when the employees are happy and satisfied with the job.

The present pandemic has affected many sectors. Many companies in India such as Larsen \& Toubro, Bharat Forge, UltraTech Cement, Grasim Industries, Aditya Birla Group, BHEL and Tata Motors have temporarily suspended or significantly reduced operations. The Young startups have been impacted as funding has dropped. Fast-moving consumer goods companies in the country have significantly declined its operations and are focusing on essentials. The Indian Government announced a variety of measures to handle the situation, from food security and extra funds for healthcare and for the states, to sector related incentives and tax deadline extensions.
The coronavirus (COVID-19) is affecting and disrupting the manner in which individuals live and work globally. Numerous organizations are indulging in remote working directives to safeguard the wellbeing of employees. Organizations need to assess existing remote working programs or quicken the development of new programs that can empower employees to work effectively during the coronavirus pandemic. In each industry, each employee is performing a corporate role. Organizations across divisions are concentrating on moving forward.

However, working remotely isn't a new concept, most people are familiar with working remotely. Work from home has become the new reality for most of us. Due to covid-19, it is difficult to continue the company's operations with a smaller number of people working in the company and many employees have to work from home

Most of the employees will be working in full-time remotely for the first time, and that is not easy for the organization to manage effective work with the full workforce working from home. Likewise, employees may find themselves struggling to stay effective in new task and new environment to manage everything on their own.

\section{Literature Review}

Viswesvaran and Ones (2000) presented job performance as behavior and outcome (productivity) that employees undertake to contribute to organizational mission ${ }^{2}$. Job performance denotes the efficiency of individual behaviors that contribute to organizational goals and must comprise of job performance and contextual performance. Performance of employees can also be determined through the combination of expected behavior and taskrelated aspects (Motowidlo, 2003) ${ }^{3}$, even though 
performance is determined by financial data. In certainty, performance that is based on an absolute value may reflect total organizational performance (Gomez- Mejia, Balkin and Cardy, 2007; Wall et al., 2004) ${ }^{4}$. Employee performance is a significant variable in work organization (Suliman, 2001) and has become an important indicator in determining performance of organization in many studies (Wall et al., 2004) ${ }^{5}$. But Wiedower (2001) emphasized that performance measure that is based on the performance appraisal items offers higher reliability in estimating employees' performance ${ }^{6}$.Employees high performance pursue higher level of individual and organizational performance which comprise productive, quality, innovation and cycle time of performance (Bharadwaj, 2005) and thus they will be able to assist organization to accomplish its planned goals and supporting the organization competitive advantage (Dessler, 2011) ${ }^{7}$.

Work performance is defined as activities, actions or behaviors related to organizational goals (Campbell, $1990)^{8}$, it includes both productive and counterproductive worker behaviors that contribute to organizational objectives (Hunt, 1996) ${ }^{9}$. Both the concepts are influenced by different factors, for instance job-related experience determines task performance while individual's personality type determines contextual performance (Motowidlo and Van Scotter, 1994) ${ }^{10}$.

\section{Objectives of the Study}

1. To identify the essential factors influencing the employee performance during covid-19 pandemic.

2. To identify the recent practices adopted in IT companies to improve performance of employees during covid-19.

\section{RESEARCH METHODOLOGY}

Descriptive Research Design is adopted in the study. It is concerned with the describing the socio-economic characteristics such as age, gender, education qualification, marital status, monthly income, work experience and nature of family.

Both primary and secondary data used for the present study. The primary data was collected from 60 respondents from Chennai for collecting the first-hand information from the IT employees. The secondary data has been collected from Books, websites, journals etc. The question is designed for the present study has two sections, the first section consists of demographic information and the second section consists of five-point Likert scale questions on Work performance of employees during COVID - 19.

SPSS "Statistical Package for Social Science" was used to perform statistical analysis of the data collected through the questionnaire method. The methodologies used for the present study is descriptive statistics and factor analysis. Factor analysis was used to identify smaller number of factors underlying a large number of observed variables. Factor loadings help in identifying which variables are associated with the particular factors ${ }^{1}$.

\section{Data Analysis and Interpretation}

The data collected were systemically processed, tabulated and made suitable for analysis and interpretations. The data has been collected from 60 respondents and the work performance includes five-point Likert scale with 15 variables and 3 factor loadings under appropriate components.

\section{Frequency Table 1}

\begin{tabular}{|c|c|c|}
\hline & Frequency & Percentage \\
\hline \multicolumn{3}{|l|}{ Age } \\
\hline $18-24$ & 15 & 25 \\
\hline $25-34$ & 33 & 55 \\
\hline $35-45$ & 12 & 20 \\
\hline Gender & & \\
\hline Male & 45 & 75 \\
\hline Female & 15 & 25 \\
\hline $\begin{array}{c}\text { Marital status } \\
\text { Married }\end{array}$ & 22 & 36.7 \\
\hline Unmarried & 38 & 63.3 \\
\hline $\begin{array}{c}\text { Family type } \\
\text { Joint }\end{array}$ & 22 & 36.7 \\
\hline Nuclear & 38 & 63.3 \\
\hline $\begin{array}{l}\text { Educational level } \\
\text { Bachelor's degree }\end{array}$ & 35 & 58.3 \\
\hline Master's degree & 25 & 41.7 \\
\hline $\begin{array}{c}\text { Income level } \\
0-19,999\end{array}$ & 28 & 46.7 \\
\hline $20,000-39,999$ & 14 & 23.3 \\
\hline $40,000-59,999$ & 4 & 6.7 \\
\hline Above 60,000 & 14 & 23.3 \\
\hline $\begin{array}{l}\text { Work experience } \\
6 \text { months }-2 \text { year }\end{array}$ & 17 & 28.3 \\
\hline 2 years -4 years & 31 & 51.7 \\
\hline Above 4 years & 12 & 20 \\
\hline
\end{tabular}

\section{Interpretation}

From the above table no 1.1 , we infer that $25 \%$ are female and $75 \%$ are male in this study. Whereas $25 \%$ belong to 18 -24 age category, $55 \%$ belong to $25-34$ age category, $20 \%$ belong to $35-45$ age category. $36.7 \%$ belong to joint family, while $63.3 \%$ belong to nuclear family. $36.7 \%$ are married respondents and $63.3 \%$ are unmarried respondents. And 58.3\% earned bachelor's degree, while $41.7 \%$ got master's degree. And $28.3 \%$ have work experience of 6 months -2 years and only $12 \%$ have above 4 years work experience. From the above table we infer 
that $46.7 \%$ earn below 19,999 and $23.3 \%$ of the respondents earn between $20,000-39,999$. And $23.3 \%$ earn above 60,000.

Table 2: KMO and Bartlett's Test

\begin{tabular}{|l|r|r|}
\hline $\begin{array}{l}\text { Kaiser-Meyer-Olkin Measure of Sampling } \\
\text { Adequacy. }\end{array}$ & .647 \\
\hline $\begin{array}{l}\text { Bartlett's Test of } \\
\text { Sphericity }\end{array}$ & Approx. Chi-Square & 1370.941 \\
\hline & df & 105 \\
\hline & Sig. & .000 \\
\hline
\end{tabular}

\section{Interpretation}

The researcher after computing exploratory factor analysis for IT employees work performance in Chennai during COVID - 19 lockdowns has identified the KMO sampling adequacy is satisfied with the scale of measures. Based on $\mathrm{KMO}$ measure value should be greater than 0.60 to 0.70 while computing the result as it is mentioned by the eminent research your name the Brandon et.al (2003). As mentioned earlier the Barlett's test of Sphericity resulted with main aspects with approximate Chi square value as 1370.941 as it is also considered as an effective result. Degrees of freedom implies the 105 as a freedom value and the final level of significance is. 000 as it is less than 0.05 under the probability value. Hence the study resulted in a valid output with greater significance value in order to deliver the concept in effective manner.

Table 3: Communalities

\begin{tabular}{|l|l|l|}
\hline & Initial & Extraction \\
\hline $\begin{array}{l}\text { I properly structure my day } \\
\text { while working remotely }\end{array}$ & 1.000 & .872 \\
\hline $\begin{array}{l}\text { I find it easy to focus and to } \\
\text { resist interruption while } \\
\text { working remotely }\end{array}$ & 1.000 & .729 \\
\hline $\begin{array}{l}\text { I feel productive while } \\
\text { working remotely }\end{array}$ & 1.000 & .671 \\
\hline $\begin{array}{l}\text { Working remotely does not } \\
\text { negatively affect the outcome } \\
\text { of my daily work }\end{array}$ & 1.000 & .920 \\
\hline $\begin{array}{l}\text { Working remotely does not } \\
\text { negatively influence my work } \\
\text { morale }\end{array}$ & 1.000 & .881 \\
\hline $\begin{array}{l}\text { My firm is providing the right } \\
\text { tool stack to enable } \\
\text { teamwork while working } \\
\text { remotely. }\end{array}$ & & \\
\hline $\begin{array}{l}\text { Working remotely does not } \\
\text { have a negative effect on } \\
\text { teamwork }\end{array}$ & 1.000 & .786 \\
\hline
\end{tabular}

We are staying connected as a team despite working 1.000 .945 remotely

I feel easy to get input and feedback from my manager while working remotely.

My manager is frequently checking in with me while working remotely

1.000 .800

The organization is communicating properly with everyone working remotely.

Able to sustain a good worklife balance while working remotely

I do not expect the remoteness of working remotely to negatively affect my health.

I have the right equipment (e.g. desk, internet access) and tools to be effective while working remotely.

I have the right environment (e.g. quiet \& free space) while working remotely.

Extraction Method: Principal Component Analysis.

\section{Inference for Communalities}

The term communalities are accumulated with two aspects namely initial value and the extracted value. As per the communality terms the majority of the result of the initial value should be greater than 1 and after the extraction the value should be greater than .4 with higher level of significance. Based on the results delivered in the communities the grouping factors loaded with highly significant value and extremely satisfied the main concept variables such as WP 5 are loaded with value greater than point .9 which clearly shows higher significance in the current study. Secondly, the variables such as WP 7, WP 9, WP 14, WP 15, WP 2, WP 13 are loaded with the value greater than .8 which clearly shows greater significance in the current study. Thirdly the variable such as WP 4, WP 12, WP 3, WP 10, WP 6 are loaded with the value greater than .7 which clearly shows significance in the current study. As per the result of exploratory factor analysis the variable WP 12 resulted the value point .713 and specified that employees are able to sustain a good work-life balance while working remotely. 
Table 4: Total Variance Explained

\begin{tabular}{|c|c|c|c|c|c|c|c|c|c|}
\hline \multirow[t]{2}{*}{ Component } & \multicolumn{3}{|c|}{ Initial Eigenvalues } & \multicolumn{3}{|c|}{$\begin{array}{c}\text { Extraction Sums of Squared } \\
\text { Loadings }\end{array}$} & \multicolumn{3}{|c|}{ Rotation Sums of Squared Loadings } \\
\hline & Total & $\begin{array}{c}\% \text { of } \\
\text { Variance }\end{array}$ & $\begin{array}{c}\text { Cumulative } \\
\%\end{array}$ & Total & $\begin{array}{c}\% \text { of } \\
\text { Variance }\end{array}$ & $\begin{array}{c}\text { Cumulative } \\
\%\end{array}$ & Total & $\begin{array}{c}\% \text { of } \\
\text { Variance }\end{array}$ & $\begin{array}{c}\text { Cumulative } \\
\%\end{array}$ \\
\hline 1 & 7.993 & 53.289 & 53.289 & 7.993 & 53.289 & 53.289 & 4.888 & 32.589 & 32.589 \\
\hline 2 & 2.569 & 17.128 & 70.417 & 2.569 & 17.128 & 70.417 & 3.707 & 24.716 & 57.305 \\
\hline 3 & 1.604 & 10.697 & 81.114 & 1.604 & 10.697 & 81.114 & 3.571 & 23.809 & 81.114 \\
\hline 4 & .922 & 6.148 & 87.262 & & & & & & \\
\hline 5 & .701 & 4.674 & 91.936 & & & & & & \\
\hline 6 & .339 & 2.263 & 94.199 & & & & & & \\
\hline 7 & .302 & 2.010 & 96.209 & & & & & & \\
\hline 8 & .210 & 1.399 & 97.608 & & & & & & \\
\hline 9 & .132 & .881 & 98.489 & & & & & & \\
\hline 10 & .090 & .599 & 99.087 & & & & & & \\
\hline 11 & .059 & .394 & 99.481 & & & & & & \\
\hline 12 & .039 & .262 & 99.743 & & & & & & \\
\hline 13 & .023 & .153 & 99.897 & & & & & & \\
\hline 14 & .014 & .093 & 99.990 & & & & & & \\
\hline 15 & .002 & .010 & 100.000 & & & & & & \\
\hline
\end{tabular}

\section{Inference}

The above table displays the total variance explained at three stages for factors that implies the work performance of IT employees in Chennai during COVID - 19 lockdowns. Three factors were extracted because their eigenvalues greater than 1 . When three factors were extracted, then 81.114 percent of the variance would be explained.

Table 5: Rotated Component Matrix

\begin{tabular}{|l|c|c|c|}
\hline & \multicolumn{3}{|c|}{ Component } \\
\hline WP 5 & $\mathbf{1}$ & $\mathbf{2}$ & $\mathbf{3}$ \\
\hline WP 7 & .904 & & \\
\hline WP 9 & .858 & & \\
\hline WP 4 & .811 & & \\
\hline WP12 & .739 & & \\
\hline WP14 & .713 & & \\
\hline WP15 & & .845 & \\
\hline WP 2 & & .812 & \\
\hline WP 1 & & .809 & \\
\hline WP 11 & & .678 & \\
\hline WP 13 & & .560 & \\
\hline WP 3 & & & .821 \\
\hline WP 10 & & & .792 \\
\hline WP 6 & & & .780 \\
\hline WP 8 & & & .729 \\
\hline
\end{tabular}

\section{Inference}

The above table shows the rotated factor matrix for the questionnaire. Variables with factor loadings more than .5 was chosen in this study because loadings .5 is considered average where is loading. 4 is considered less good after performing varimax rotation method with Kaiser Normalisation. Factor 1 comprised of 5 items with factor loadings ranging from. 7 to .9. The items in factor 1 are WP 5, WP 7, WP 9, WP 4 and WP 12. Factor 2 comprised of five items with factor loadings ranging from point .5 to .8 . The items in the factor 2 are WP 14, WP 15, WP 2, WP 1 and WP 11. Factor 3 comprised of five items with factor loadings ranging from .6 to .8. The items in factor 3 are WP 13, WP 3, WP 10, WP 6 and WP 8.

\section{Grouping Factor}

1. The factor "Work life balance" explains the $1^{\text {st }}$ component.

2. The factor "Work environment" explains the $2^{\text {nd }}$ component.

3. The factor "Communication" explains the $3^{\text {rd }}$ component.

From the above table, it is very clear that 1st component (i.e) Work life balance factor has higher factor loadings with .904 , it implies that a healthy teamwork is ideal when it comes to maintaining a positive outcome. An increasing number of companies are depending on their employees to lead a better-balanced lifestyle, happy employees are more productive and efficient. When working from home it is significant for maximum motivation and productivity to have a comfortable home office environment to formulae profitable strategies. When remote teams communicate 
well, they can actually gain an advantage over co-located teams. All the tools and accessories are vital to bring the best from the employee and their teams.

\section{Findings}

1. Under the factor 'Work environment', WP5 has been recorded with highest loading of .904 which indicates working remotely does not influence the employees work morale.

2. The statement 'Working remotely does not have a negative effect on teamwork' has the factor loading of .858 portrays that they stay connected as a team despite the lockdown.

3. Under the factor 'work environment', WP 14 has the factor loading of .845 indicates that the employees are having the right equipment for their work.

4. The statement 'I find it easy to focus and to resist interruption while working remotely' has been recorded with .809 under the factor 'work environment'.

5. The statement "I do not expect the remoteness of working remotely to negatively affect my health" has been recorded with .821 under the factor 'Communication'

6. Under the factor 'Communication' WP 10 has the factor loading of .780 indicates that there is a frequent checking of employees work by the manager.

\section{Suggestions}

Since work-from-home is becoming a usual routine for several, managers or supervisors should boost their employees to create a separate work office in their homes for good performance. Management should make ensure that their teams succeed by providing the tools they need to stay connected and work effectively. Equipping them with tracking apps like Asana, chat apps like Slack and Microsoft Teams, and video conferencing apps like Google Hangouts and Zoom. Ensuring that all of the office computers are working in good condition when employees plan on bringing the laptop to their home. Making sure that all employees keeps their apps updated and they have a proper speed internet connection. Checking daily via video/ phone calls or instant messages makes a sense of belonging among the employees.

\section{CONCLUSION}

Despite the current COVID - 19 lockdowns, many companies are practicing work from home. There will be a change in the work environment, the employees should have proper access to essential resources while working remotely. There should be a continuous access to internet connection, comfortable desk facility, proper lightning etc. Communication is a very essential during these times, without communication there will no effective results. The employees should be frequently monitored by their mangers or superiors, so that the performance of the employees can be maintained at the times of lockdown.

\section{REFERENCES}

1. Dr. R. Angayarkanni and V. Sathyavathi (2019). A Study on enriching Work Environment on Personnel job satisfaction with special reference to Wipro company in Chennai. e ISSN 2348 -1269, Print ISSN 2349-5138.

2. Viswesvaran, C., \& Ones, D. S. Perspectives on models of job performance. International Journal of Selection and Assessment, 8(4), 2000, 216-226.

3. Motowidlo, S. J. Job performance. In W. C. Borman, D. R. Ilgen, \& R. J. Klimoski (Eds.), Handbook of psychology: Industrial and organizational psychology, Vol. 12, 2003, 3953).

4. Gomez-Mejia, L. R., Balkin, D. B. \& Cardy, R. L. Managing Human Resources. Pearson Education, New Jersey. 2007.

5. Wall, T. D., Michie, J., Patterson,M., Wood, S. J., Sheehan, M., Clegg, C. W., \& West, M. On the validity of subjective measures of company performance. Personnel Psychology, 57, 2004, 95-118.

6. Wiedower, K. A. 2001. A shared vision: the relationship of management communication and contingent reinforcement of the corporate vision with job performance, organizational commitment, and intent to leave, Unpublished Doctoral Diss., Alliant International University, California.

7. Dessler, G. Human Resource Management. Pearson Education Limited, Upper Saddle River. 2011.

8. Campbell, J. Modeling the performance prediction problem in industrial and organizational psychology. In M. Dunnette \& L. Hough (Eds.), Handbook of industrial and organizational psychology, 1990, (pp. 686-707).

9. Hunt, S. T, Generic work behavior: An investigation into the dimensions of entry-level, hourly job performance. Personnel Psychology, 49(1), 1996, 51-83.

10. Motowidlo, Stephan \& Van Scotter, James. Evidence That Task Performance Should Be Distinguished From Contextual Performance. Journal of Applied Psychology. 79, 1994, 475480. 10.1037/0021-9010.79.4.475.

11. Retrieved from Economic impact of the COVID-19 pandemic in India from Wikipedia

12. Retrieved from https://hbr.org/2018/02/how-tocollaborate-effectively-if-your-team-is-remote

13. Retrieved from https://www.ionos.com/startupguide/productivity/worklife-balance

\section{Source of Support: None declared.}

Conflict of Interest: None declared. 